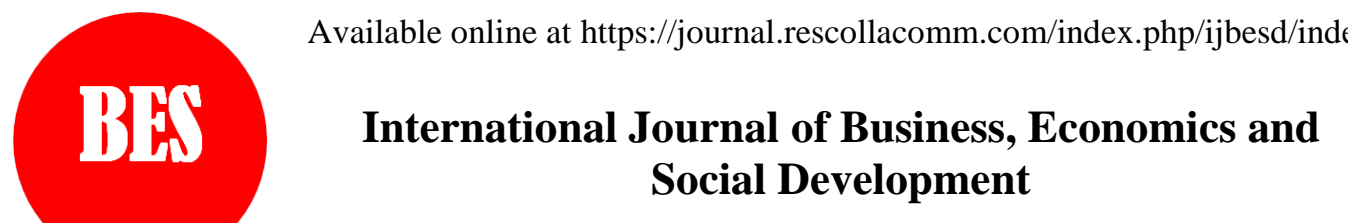

Vol. 2, No. 2, pp. 57-64, 2021

\title{
The Effect Of Zakat On Income Disparity In Aceh Province
}

\author{
Oka Fadliansah*, Suriani Suriani, Eddy Gunawan \\ Department of Economics, Faculty of Economics and Business, Universitas Syiah Kuala, Darussalam, Banda Aceh, Indonesia
}

*Corresponding author email: okafadliansyah@gmail.com

\begin{abstract}
This study analyzes the effect of zakat funds, human development index, Gross Domestic Product, and poverty on income inequality in 21 districts/cities in Aceh Province. This study uses panel data from 21 districts/cities in Aceh Province for the 2010-2019 period. The results found the regression coefficient of zakat funds have a positive relationship with a significance level of 0.08 , which means that an increase in zakat funds of $1 \%$ will increase income inequality by 0.011 points. Then the human development index variable has a negative effect with a significant level of income inequality of 0.000 , which means that each human development index increases by $1 \%$, it will reduce income inequality by 0.12 points. Furthermore, the poverty variable that can describe the role of income inequality, the results obtained have no effect on income inequality in 21 districts/cities of Aceh Province during the study period. Then the last variable is Gross Domestic Product which has a negative relationship with a significance level of 0.0049 on income inequality in 21 districts/cities in Aceh Province during the study period. The resulting regression coefficient is $0.011 \%$, which means that when the Gross Regional Domestic Product increases by $1 \%$, it will reduce income inequality by 0.011 points.
\end{abstract}

Keywords: Income disparity, zakat funds, human development index, poverty, GDP.

\section{Introduction}

This inequality is usually due to the inequality of development in an area or in a country so that it has not been able to create the expected income distribution (Kavya and Shijin, 2020). Income inequality is related to the distribution of income received by the people of a country or region. The higher the income inequality, the more uneven the distribution of income in an area, this condition will eventually enlarge the gap between people with high incomes and people with low incomes (Koh et al., 2020). Economic growth without being accompanied by a decrease in disparity will enlarge the gap between one group and another in society, as well as when economic development without being accompanied by economic growth will increase the poverty rate. Therefore, the benchmark for the success of economic development in an area is seen from its economic growth, poverty level, human development and income inequality (Idowu and Adeneye, 2017; Sukono et al., 2020; Pusra et al., 2021). One of the causes of income disparity is rampant poverty, increasing population distribution, low economic growth, and difficulty in accessing various services, such as education and health. Where do we know? The low rate of economic growth, the number of people who always experience an increase but are not productive, the rising unemployment rate, and the increasing percentage of the poor, tend to have an impact on the occurrence of crime everywhere. When this happens, a very big problem will arise, especially in Indonesia, identical to developing countries, it will be very easy to trigger unwanted events (Hailemariam and Dzhumashev, 2019; Maulana et al., 2020). One of the efforts to overcome these problems is the need for government encouragement, especially in increasing economic development, alleviating poverty, increasing the human development index and utilizing existing sources of funds so that economic development can be absorbed evenly.

Aceh Province, one of the regions that have special autonomy rights, especially in managing the existing wealth, of course, has its own problems in running the economy, such as problems with economic growth, poverty, human development, and income disparity problems. Income disparity is a problem that often occurs in every country, both developed and developing countries.

The economic growth rate of Aceh Province experienced a fluctuating trend, but in 2015 economic growth decreased by $-0.73 \%$. This is due to the decline in oil and gas production in both the mining and industrial sectors. For the 2016 to 2019 period, Aceh's economic growth has improved from $3.29 \%$ to $3.54 \%$. Economic growth increased 
that year, driven by developments in the business world, especially in the service sector, so that the Aceh Province's economic growth tended to improve from the previous year's period (Heger and Neumayer, 2019).

When economic growth fluctuates. The percentage of poor people decreased during the period 2010 to 2019 . According to the Central Statistics Agency for Aceh Province, there has been a decrease in the percentage of people by $0.02 \%$. This is due to government breakthroughs, especially in the field of development, one of which is the realization of village funds which reached $99.9 \%$. Then various other sources of financing so that in general the number of poor people has decreased over the last ten years from $20.98 \%$ to $15.32 \%$. Furthermore, in 2019 although the economic growth of Aceh Province experienced a slowdown due to the number of delayed projects and programs financed from the government budget, the high dependence on the oil and gas sector, the percentage of the poor population decreased by $15.52 \%$ from the previous year of $15.97 \%$

Meanwhile, when economic growth fluctuates and the percentage of poor people decreases, the human development index also changes in line with the decline in the percentage of poor people and the increase in economic growth in recent years. The Human Development Index has increased from 67.45 points to 71.90 points for the 20102019 period (Heger and Neumayer, 2019). This illustrates that when the rate of economic growth experiences a positive trend, it will reduce the percentage of the number of poor people and is followed by the development of the quality of human resources in Aceh Province which is increasing.

However, when economic growth fluctuates and the percentage of the poor decreases and is followed by the development of the human development index, the fact is that it has not been able to provide welfare for the people in Aceh Province. One alternative in Islamic economics to overcome income inequality is to collect zakat funds and distribute zakat on target.

The realization of the overall distribution of zakat funds in various regions reached 54 billion in 2010 and continued to increase into the following year. The distribution of zakat funds in 2019 reached 158 billion, and this is the highest number in the last ten years. The more zakat funds issued; the recipients will also increase. With a large number of zakat funds distributed to various regions in Aceh Province, it can affect the community's economy, especially for the less fortunate or the lower-middle-class economy.

The income inequality can be reduced through government spending, such as zakat funds, improving the quality of human resources (HDI), economic growth, and the number of poor people. In addition to supporting data, related research also contributes to income inequality (Suriani et al., 2020). The Zakat has a one-way causal relationship with poverty and income inequality, meaning that if the distribution of zakat funds is carried out optimally, it will reduce poverty and income inequality. The Human Development Index affects reducing income inequality between districts/cities in East Java Province. Improving the quality of human resources through education and health can be regarded as a form of investment. The education received by people in disadvantaged areas encourages opportunities for them to master modern technology. Modern technology will be especially useful in increasing productivity or production efficiency so that people's incomes are higher and will contribute in the future. The Economic growth reduces income inequality in Indonesia (Nugraha and Lewis, 2013). Where every $1 \%$ increase in GDP will reduce income inequality in Indonesia by $0.0256 \%$. Every economic sector experiencing an increase will have an impact on better labor productivity and with increasing labor productivity, the impact on income earned by the community will be higher so that income inequality will be smaller. The Poverty occurs because the minimum needs and needs are not met because the income they earn is increasing, this can be interpreted as increasing income among the community, it will reduce the gap in income differences they get so that income inequality decreases (Santika et al., 2021).

Based on the description above, the objectives that underlie this research are, first, the problem of inequality in Aceh Province has not been resolved. This can be seen from the Gini Ratio which tends to increase every year, both zakat funds as Islamic philanthropy and HDI, Economic Organizations, and poverty can reduce income inequality. Third, to prove the theory with the reality on the ground, fourth, to prove the influence of the variables of zakat funds, HDI, Gross Domestic Product, and the number of poor people on income disparity in 21 districts/cities of Aceh Province for the period 2010-2019.

\section{Literature Review}

\subsection{Income inequality theory.}

The income inequality is a concept that explains differences in prosperity, the standard of living, and income received or generated by individuals or households in society, resulting in uneven distribution between regions caused by differences in production factors and resources that exist in various regions (Rachmawati et al., 2021). There are two main concepts regarding the measurement of the income distribution, namely the concept of absolute inequality and the concept of relative inequality. The concept of absolute inequality is a concept of measuring inequality that uses a parameter with an absolute value while the concept of relative inequality is a concept of measuring inequality that compares the amount of income received by a person or group of people with the total income received by the community as a whole (Asra, 2020). 


\subsection{Economic Growth}

Economic growth can be defined as an explanation of what factors determine the increase in output per capita in the long run and how these factors interact with each other so that the growth process occurs (Idowu and Adeneye, 2017). Economic growth without being accompanied by a decrease in disparity will widen the gap between one group and another in society, as well as when economic development without being accompanied by economic growth increases the poverty rate. Therefore, the benchmark for the success of economic development in an area is seen from its economic growth, poverty level, human development, and income inequality (Peterson, 2018).

\subsection{Human development Index}

The human development index (HDI) is a single composite indicator, although it does not only measure the three main dimensions of human development which is considered to reflect the basic capabilities of the population. Of the three basic abilities, they are long and healthy life, knowledge and skills, and access to the resources needed to achieve a decent standard of living (Sofilda et al., 2015).

\subsection{Poverty}

The poverty is very closely related to income inequality. Poverty causes income inequality between the rich and the poor to get further, not achieving a reduction in the poverty rate causes income inequality in developing countries to increase. Therefore, it is necessary to reduce poverty so that income inequality among the community is lower. There are several studies related to the relationship between poverty and income inequality, which have two different directions, namely a positive relationship and a negative relationship (Pusra et al., 2021).

\subsection{Zakat}

Zakat Fund is a levy or mandatory tax collected by Islamic countries from people who can afford it and then distributed or issued to the underprivileged or poor. Qualitatively it will be blessed and will grow, quantitatively the number will decrease (Saputro and Sidiq, 2020).

\subsection{The effect of zakat funds on income inequality}

Zakat is a levy or mandatory tax collected by Islamic countries from people who are able and distributed or issued to underprivileged or poor communities. Qualitatively it will be blessed and will grow, although quantitatively the number will decrease. Zakat aims to realize socio-economic justice for low-income people. One way to reduce income disparities is through the utilization and optimization of zakat instruments (Ibrahim et al., 2020). If zakat is managed properly, it will have an impact on increasing people's income. With this additional income, the community can meet existing needs, one of which is the need for food and clothing. Zakat is more successful and empowered by maximizing the role of Amil in collecting and distributing it to groups who are entitled to receive zakat to meet basic needs and not only run out for consumptive assistance, providing entrepreneurship training and financial management according to the mustahik. ability to run well. In addition, it can also provide moral motivation to continue to be consistent in running a business to be able to lead to independence.

\subsection{The effect human development index on income inequality}

The formal education in supporting economic growth, which means that the higher the formal education obtained, the productivity of the workforce will increase (Meisami et al., 2011). This is by the Human capital theory which states that education has an influence on economic growth and will reduce income disparities because education can play a role in increasing individual labor productivity. When a person has a high income due to his education, the economic growth of each population can be supported and the impact on economic growth either directly or indirectly will hurt income inequality.

\subsection{The relationship of poverty to income inequality.}

Salim et al. (2020) while in the long term there is a positive relationship between poverty and income inequality. This implies that in a certain proportion, poverty is indeed related to income inequality, but reduced poverty does not mean reducing income inequality, but lower poverty increases income inequality. So, that solutions or measures to reduce poverty can be in favor of inequality but are allowed to increase income inequality. 


\subsection{The effect of economic growth on income inequality.}

Economic growth can be interpreted as the development of activities in the economy that causes goods and services produced in society to increase. In this context, it is assumed that the level of prosperity of an area is seen in terms of the average income received by its residents. The higher the income, the higher the purchasing power of the population, and this increased purchasing power will increase the welfare of the community (Raekyesa, 2020).

\subsection{The influence of zakat funds, Human Development Index, Gross Domestic Product, and Poverty on income inequality.}

Zakat has a one-way causal relationship with poverty, which means that if the distribution of zakat funds is carried out optimally, it will reduce poverty and income inequality. The Economic growth has a real influence on income inequality, in this context, it is assumed that the level of prosperity of an area is seen in terms of the average income received by its population. The higher the income, the higher the purchasing power of the population, and this increased purchasing power will increase the welfare of the community. The poverty occurs because the minimum needs are not met and the minimum needs are met due to the increasing income they earn, this can be interpreted as increasing income among the community, it will reduce the gap between the income differences they get, so that income inequality increases decreased.

\section{Methods}

The scope of this research is to analyze the effect of zakat funds, human development index, Gross Domestic Product, and poverty on income inequality in Aceh Province (21 districts/cities). The data structure used is panel data, cross-sections from 21 districts/cities, and time series for the 2010-2019 period in Aceh Province. The independent variables are Zakat Fund, Human Development Index, Gross Domestic Product, and Poverty, while the dependent variable in this study is Income Inequality. Furthermore, the source of the data obtained came from the Central Statistics Agency (BPS) of Aceh Province and Baitul Mal of Aceh Province. Then the data used is the Gini Ratio for each of the 21 districts/cities in Aceh Province. Realization of Zakat Fund Receipts in each of the 21 districts/cities in Aceh Province. Human Development Index for every 21 districts/cities in Aceh Province, Gross Domestic Product for every 21 districts/cities in Aceh Province. The number of poor people in each of the 21 districts/cities in Aceh Province.

To answer the above problems, the model and analysis method used in this study is a panel data regression model using the help of Eviews 10 Software.

Considering that panel data is a combination of Cross Section and time-series data, the model is written as

$$
\mathrm{GR}_{\mathrm{it}}=\alpha+\beta_{1} \mathrm{DA}+\beta_{2} \mathrm{HDI}+\beta_{3} \mathrm{KMN}_{\mathrm{it}}+\beta_{4} \mathrm{GDP}_{\mathrm{it}}+\varepsilon_{\mathrm{it}}
$$

Where :

GR : Gini Ratio (for the i- region and t-time)

DA : Zakat Funds

IPM : Human Development Index

KMN : Poverty

GDP : Gross Domestic Product

$\alpha \quad$ : Intercept or constant

$\beta 1,2,3$ : Independent variable regression coefficient

i : Aceh Province Cross-Section Data

t $\quad$ : Time Series data for 2010-2019

Panel data regression, before estimating the model, testing is needed to find out the best method for estimating equation parameters with panel data, three method techniques can be done, namely :

\section{a. Cammon Effect Model}

Cammon effect model is the simple technique for estimating panel data regression. This approach ignores the heterogeneity between the same Cross Section units in time. In estimating the Cammon Effect model, the Ordinary Last Square (OLS) method can be used. The common effect model can be expressed as follows:

$$
\mathrm{Y}_{\mathrm{it}}=\alpha+\beta_{1} \mathrm{X}_{1 \mathrm{it}}+\beta_{2} \mathrm{X}_{2 \mathrm{it}}+\beta_{3} \mathrm{X}_{3 \mathrm{it}}+\beta_{3} \mathrm{X}_{4 \mathrm{it}}+\varepsilon_{\mathrm{it}}
$$




\section{b. Fixed effect Model}

This model assumes that the intercept may differ between individuals but the intercept of each individual does not vary over time (Ratnasari et al., 2014).

$$
Y_{i t}=\alpha+\beta_{1} X_{1 i t}+\beta_{2} X_{2 i t}+\beta_{3} X_{3 i t}+\beta_{3} X_{4 i t}+\varepsilon_{i t}
$$

Intercept as it, this means that each individual's intercept is time-variant. In addition, as shown in the above equation, FEM assumes that the coefficients of the regression do not vary between time and between individuals.

c. Random effect Model

This model assumes that the difference between the intercepts and constants is caused by errors as a result of differences between units and between periods that occur randomly. Because of this, the random effect model is often called the error component.

$$
Y_{i t}=\alpha+\beta_{1} X_{1 i t}+\beta_{2} X_{2 i t}+\beta_{3} X_{3 i t}+\beta_{3} X_{4 i t}+\left(\varepsilon_{i t}+u_{i}\right)
$$

Before estimating, a model specification test is conducted to determine the model to be used.

\section{- Chow test}

The chow test is a test to determine whether the common effect or fixed effect model is the most appropriate for panel data estimation.

The hypothesis is as follows:

H0: the model follows the common effect

Ha: the model follows the fixed effect

- Hausman Test

The Hausman test is a test used to determine the best method between fixed effects or random effects.

Hausman test testing is done with the following hypothesis:

H0: the model follows the random effect

Ha: the model follows the fixed effect

\section{Results and Discussion}

Panel data regression analysis was conducted to select an estimation model between common effects, fixed effects, and random effects as described previously. Furthermore, the process of selecting the best model is carried out through stages by selecting the common effects and fixed effects models using the Chow test.

Based on the results of the Chow test analysis with the probability value of the F statistical test of 0.000 , which means rejecting the null hypothesis so that the fixed effect model is better than the comment effect model (See Table $1)$.

Table 1. Chow Test

\begin{tabular}{llll}
\hline Effects Test & Statistic & d.f. & Prob. \\
Cross-section F & 7.697277 & $(20,185)$ & 0.0000 \\
Cross-section Chi-square & 127.151555 & 20 & 0.0000 \\
\hline
\end{tabular}

After testing these stages, then selecting the best model between the fixed effects model and the random-effects model using the Hausman test (See Table 2).

Table 2. Hausman Test

\begin{tabular}{llll}
\hline Test Summary & Chi-Sq. Statistic & Chi-Sq. d.f. & Prob. \\
Cross-section random & 10.094518 & 4 & 0.0389 \\
\hline
\end{tabular}


The results of these tests the statistical value obtained are 0.0389 . Where the results of this statistical test are compared with the test level of $5 \%$, which means that the fixed effects model is better than the random-effects model so that the best model obtained in this study is the fixed effects model (See Table 3).

Table 3. Estimation Results with fixed effects model

\begin{tabular}{lrr}
\hline \multicolumn{1}{c}{ Variable } & Coefficient & Prob. \\
\hline ZAKAT_FUND & 0.114382 & 0.0869 \\
HUMAN_DEVELOPMENT_INDEX & -0.125134 & 0.0000 \\
POVERTY & 0.004277 & 0.2905 \\
GDP & -0.011425 & 0.0049 \\
CONSTANTA & 0.218889 & 0.2691 \\
\hline R-squared & 0.252295 & \\
Adjusted R-squared & 0.202702 & \\
F-statistic & 5.087348 & \\
Prob(F-statistic) & 0.000000 & \\
\hline
\end{tabular}

Statistically, the estimation by using the eviews 10 application is fit. This is evidenced by the R-squared value of 0.25 which means that the variables of Zakat Fund, Human Development Index, Gross Domestic Product, and Poverty together have a relationship with Income Inequality in 21 districts/cities of Aceh Province by $25 \%$. Then the F-statistical significance value of 0.000 which is smaller than the $5 \%$ test level shows that together the variables of Zakat Fund, Human Development Index, Gross Domestic Product, and Poverty affect income inequality in 21 districts/cities of Aceh Province worth $5.08 \%$.

Furthermore, the regression analysis model can be formulated as follows:

$$
\begin{aligned}
& \mathrm{GR}=+0.218889+0.114382 \text { LOG }\left(\text { ZAKAT FUND }_{\mathrm{it}}\right) * *-0.125134 \mathrm{LOG}\left(\mathrm{HDI}_{\mathrm{it}}\right)^{*} \\
& \quad+0.004277 \mathrm{LOG}(\mathrm{POVERTY} \\
& \mathrm{it})-0.011425 \mathrm{LOG}\left(\mathrm{GDP}_{\mathrm{it}}\right) *
\end{aligned}
$$

The variable zakat funds have a positive relationship with a significance level of 0.08 , which means that an increase in zakat funds by $1 \%$ will increase income inequality by 0.011 points in 21 districts/cities of Aceh Province. This is very surprising because it contradicts the theory when zakat funds increase, it will reduce income inequality. This is because the distribution of zakat funds is not only channeled to the middle to lower economic community but the distribution of zakat funds is also channeled to social development such as the construction of Islamic boarding schools and educational scholarships for underprivileged children so that the portion received by the middle and lower economic community from the distribution of funds. zakat only to meet daily needs. Furthermore, there are indications that the distribution of zakat funds has not been optimal so that people who are truly poor have not been able to increase their level of welfare through the distribution of zakat funds.

Suriani et al. (2020) analyzed the zakat as Islamic economic philanthropy has the potential to support government programs in poverty alleviation, the effect shown in the regression results is -2.359694 , which means that if there is an increase of one $\%$ of zakat realization, poverty is estimated decreased by $2.36 \%$. Then zakat has a one-way causal relationship with poverty, which means that if the distribution of zakat funds is carried out optimally, it will reduce poverty and income inequality. This implies that there is a close relationship between income inequality and poverty, if income inequality increases, poverty will also increase, therefore income inequality in 21 districts/cities in Aceh Province can be reduced if the distribution of zakat funds can be more optimal.

Research conducted by Marbun, (2018) in various locations in North Sumatra where zakat funds have a positive relationship with a significance level of 0.0152 , which means that if zakat funds increase by $1 \%$, it will increase income inequality by $0.000228 \%$. This is because the use of zakat funds is only limited to helping the poor, orphans, disabled and sick people, repairing slum houses, and basic education costs for poor children. so that the zakat funds received by the community have not been able to reduce income inequality in North Sumatra for the 2011-2017 period.

Then the human development index variable has a negative effect toward income disparity with significance level of 0.000 , which means that if human development index variable increases $1 \%$ it will reduce income inequality by 0.12 points in 21 districts/cities of Aceh Province during year 2010-2019. This is because the increase in the human development index is in line with the increase in the quality-of-life expectancy, the quality of education, and a decent standard of living. The increasing quality of human resources in various regions will have an impact on the higher 
productivity of the workforce. The higher the productivity of the workforce, the impact on the income received by the community is increasing so that the level of community welfare is getting better and the level of inequality can be reduced.

The human development index has a negative and significant relationship to income inequality in Indonesia. This result is evidenced by a probability value of 0.000 , which means that when the human development index increases by $1 \%$, it will reduce income inequality by 0.038 points (Ilham and Pangaribowo, 2017). This is also because the high quality of human resources encourages an increase in people's income due to increased labor productivity and also needs to be underlined that the impact of inequality is to trigger better competition between regions so that the quality of human resources will be created evenly. welfare distribution. while at the same time reducing inequality in Indonesia. Furthermore, the poverty variable that can describe the role of income inequality where the results obtained do not affect income inequality in 21 districts/cities of Aceh Province during the study period. This is because there are still many areas in Aceh Province that absorb labor in the agricultural and plantation sectors but are not proportional to the land area, causing labor productivity which has an impact on the low income received by the community so that people in various regions continue to be in poverty.

In the long term there is a positive relationship between poverty and income inequality. This implies that a certain proportion of poverty is indeed related to income inequality, but poverty reduction does not mean reduced income inequality, but lower poverty increases income inequality. So that solutions or actions to reduce poverty can be in favor of increasing income inequality. The results of this study can be concluded that the poverty variable has no effect on income inequality. Income inequality in districts/cities in Aceh Province is more influenced by other factors not included in this study.

The last variable is Gross Domestic Product which has a negative relationship with a significance level of 0.0049 on income inequality in 21 districts/cities of Aceh Province during the study period. The resulting regression coefficient is $0.011 \%$, which means that when the Gross Domestic Product increases $1 \%$, it will reduce income inequality by 0.011 points. This indicates that when economic growth has increased, it will have an impact on the distribution of income more evenly in various circles of society. In this context, it is also inseparable from the government's role in taking strategic policies oriented towards increasing regional economic development, namely by expanding employment opportunities, providing better economic infrastructure, and increasing investment so that economic growth is in line with the equitable distribution of income. So that income inequality between districts/cities in Aceh Province can be minimized. The Economic growth has a negative effect on inequality in Indonesia. Where every $1 \%$ increase in GDP will reduce income inequality in Indonesia by $0.0256 \%$. This indicates that every development of economic sectors will have an impact on better labor productivity and with the increase in labor productivity, the impact on income earned by the community is higher so that income inequality is getting smaller.

\section{Conclussion}

The objective underlying this research is to analyze zakat funds, human development index, poverty, and Gross Domestic Product on income inequality in 21 districts/cities of Aceh Province for the period 2010 - 2019. The potential of Zakat Funds in Aceh Province is very large, this is also due to the large population which is supported by policies of Aceh Provincial Government. Zakat funds are used as PAD managed by Baitul Mal. Although the results of the study show that zakat funds have a positive relationship to income inequality in 21 districts/cities in Aceh Province. This is very reasonable because the distribution of zakat funds is not only channeled to one group, but the distribution of zakat funds is also distributed to the poor, the elderly, orphans, disabled and sick, repairing slum houses, and deduction costs for underprivileged children so that people who are really poor have not been able to increase their level of welfare from the distribution of zakat funds.

Coefficient of the Human Development Index is 0.12 with a significance level of 0.00 , which means that when the HDI increases by $1 \%$, it will reduce income inequality by 0.12 points. This is because when the quality of human resources is getting better, it will affect the higher labor productivity. The higher the productivity of the workforce, the impact on the income received by the community is even more so that the level of community welfare is more evenly distributed. The regression coefficient for Gross Domestic Product is 0.011 with a significance level of 0.0049, which means that when GDP is $1 \%$, it will reduce income by 0.011 points in 21 districts/cities of Aceh Province. In this context, it is also inseparable from the government's role in making policies that increase regional economic development, namely by expanding job opportunities, providing better economic infrastructure, and increasing investment so that economic growth is in line with income distribution. So that the income between districts/cities in Aceh Province can be reduced. 


\section{References}

Agusalim, L. (2016). Pertumbuhan Ekonomi, Ketimpangan Pedapatan Dan Desentralisasi Di Indonesia. Kinerja, 20(1), 53-65.

Asra, A. (2000). Poverty and inequality in Indonesia: estimates, decomposition and key issues. Journal of the Asia Pacific Economy, 5(1-2), 91-111.

Hailemariam, A., and Dzhumashev, R. (2020). Income inequality and economic growth: heterogeneity and nonlinearity. Studies in Nonlinear Dynamics \& Econometrics, 24(3), 1-33.

Heger, M. P., and Neumayer, E. (2019). The impact of the Indian Ocean tsunami on Aceh's long-term economic growth. Journal of Development Economics, 141, 102365.

Ibrahim, P., Ali, M., Muridan, M., and Jazid, A. I. M. (2020). Revisiting Zakat Distribution on Income Inequality and Welfare: The Malaysia Experience. al-Uqud: Journal of Islamic Economics, 4(1), 146-161.

Idowu, K. A., and Adeneye, Y. B. (2017). Inequality and economic growth: An analysis of 8-Panels. Journal of Economics and Public Finance, 3(2), 173-187.

Ilham, M., and Pangaribowo, E. H. (2017). Analisis Ketimpangan Ekonomi Menurut Provinsi di Indonesia Tahun 20112015. Jurnal Bumi Indonesia, 6(4), 1-12.

Kavya, T. B., and Shijin, S. (2020). Borsa _ Istanbul Review Economic development, financial development, and income inequality nexus. Borsa Istanbul Review, 20(1), 80-93.

Koh, S. G., Lee, G. H., and Bomhoff, E. J. (2020). The income inequality, financial depth and economic growth nexus in China. The World Economy, 43(2), 412-427.

Marbun, S. (2018). Pengaruh pertumbuhan ekonomi, kemiskinan dan penyaluran dana zakat terhadap kesenjangan pendapatan di Sumatera Utara periode 2011-2017 (Doctoral dissertation, Universitas Islam Negeri Sumatea Utara Medan).

Maulana, A. R. R., Zulham, T., and Sartiyah, S. (2020). Aceh Province Economic Convergence Determination. International Journal of Business, Economics, and Social Development, 1(4), 212-226.

Meisami, H., Abdolahi, M., Shahidinasab, M., and Gaeemiasl, M. (2011). Human development, poverty and income inequality from an Islam point of view and its implications for Islamic countries. 5(13), 5224-5231.

Nugraha, K., and Lewis, P. (2013). Towards a better measure of income inequality in Indonesia. Bulletin of Indonesian Economic Studies, 49(1), 103-112.

Peterson, E. (2017). Is economic inequality really a problem? A review of the arguments. Social Sciences, 6(4), 147.

Pusra, C. M., Srinita, S., and Seftarita, C. (2021). Effect of Selected Economic Sectors on Poverty. International Journal of Business, Economics, and Social Development, 2(1), 37-49.

Raeskyesa, D. G. S. (2020). Sectoral growth and income inequality in ASEAN-5 countries: case of low-middle income economies. Journal of ASEAN Studies, 8(1), 1-13.

Rachmawati, A. M., Wulandari, D., and Narmaditya, B. S. (2021). Financial Deepening and Income Inequality in Indonesia. Global Business Review, 22(1), 57-68.

Salim, A., Rustam, A., Haeruddin, H., Asriati, A., and Putra, A. H. P. K. (2020). Economic Strategy: Correlation between Macro and Microeconomics on Income Inequality in Indonesia. The Journal of Asian Finance, Economics, and Business, 7(8), 681-693.

Santika, T., Wilson, K. A., Law, E. A., St John, F. A., Carlson, K. M., Gibbs, H., and Struebig, M. J. (2021). Impact of palm oil sustainability certification on village well-being and poverty in Indonesia. Nature Sustainability, 4(2), 109-119.

Saputro, E. G., and Sidiq, S. (2020). The role of zakat, infaq and shadaqah (ZIS) in reducing poverty in Aceh province. International Journal of Islamic Economics and Finance (IJIEF), 3, 63-94.

Sofilda, E., Hermiyanti, P., and Hamzah, M. (2015). Determinant Variable Analysis of Human Development Index in Indonesia (Case For High And Low Index at Period 2004-2013). OIDA International Journal of Sustainable Development, 8(09), 1128.

Sukono, Sambas, A., He, S., Liu, H., Vaidyanathan, S., Hidayat, Y., and Saputra, J. (2020). Dynamical analysis and adaptive fuzzy control for the fractional-order financial risk chaotic system. Advances in Difference Equations, 647(1), 1-12.

Suriani., Nurdin, R., and Muhammad. (2020). Causality Relationship of Zakat, Income Inequality, and Poverty: A Panel CoIntegration Approach. International Journal of Economics and Business Administration, 8(4), 875-887. 